\title{
Getting to the point: An experimental approach to improving the identification of penetrating projectile trauma to bone caused by medieval arrows
}

\author{
Eva Forsom, Martin J. Smith \\ Faculty of Science and Technology, Department of Archaeology, Anthropology and Forensic Science, Bournemouth \\ University, Fern Barrow, Poole, Dorset BH12 5BB, UK
}

\begin{abstract}
The bow and arrow were an important part of medieval warfare, and the study of projectile injuries in skeletal assemblages has the potential to give valuable insight into the nature of conflict in this period. Projectile injuries are often overlooked in favour of sharp force trauma, and as of yet there have been no experiments looking at skeletal trauma caused by different types of medieval arrows, although several studies have examined prehistoric impact marks. The current study addresses this deficiency by examining the lesions left by three kinds of medieval arrowheads: leaf-shaped broadheads, armour-piercing bodkins, and barbed hunting broadheads, when fired from a longbow into cattle scapulae. The results show that the vast majority of impacts are puncture lesions with shapes that roughly conform to the cross-section of the heads used, and many of the defects perforate the bone entirely and have internal bevelling. Based mostly on wound shape, it is relatively straightforward to distinguish between bodkin and broadhead punctures, while the different types of broadheads leave more similar, yet distinctive, marks. Further experiments are required in order to assess the extent to which it is possible to distinguish between projectile trauma and penetrating trauma made by other types of medieval weapons.
\end{abstract}

\section{Introduction}

\subsection{Overview}

The study of human conflict in the past is an area where biological anthropology can be of great value through interpretation of weapon related trauma in archaeological remains (Boylston, 2000; Knüsel and Smith, 2014; Lambert, 1997; Milner et al., 1991). The bow has been an instrument of hunting and war that appeared at various times in most world regions from the Upper Palaeolithic onwards and was very important for medieval warfare in England (Hardy, 1992: 12-13; Shea, 2006; Waller, 2007). Archery requires a certain amount of skill and training, and the bow is specifically designed to kill. This means that projectile traumafound on archaeological human remains is more likely to have been inflicted intentionally than by accident, and that the examination and interpretation of projectile injuries can give researchers valuable insight into past violence and conflict throughout history (Lambert, 1997). Based on observations of projectile injuries in a $19^{\text {th }}$ century living population, it appears that the majority affected the soft tissues of the postcranial skeleton and not bone (Bill, 1862). Consequently, the observed frequency of such trauma in skeletal remains will invariably be an underestimate (Lambert, 1997; Milner, 2005; Smith et al., 
2007). This makes consistent recognition of archaeological projectile trauma from all historical periods important, a process which requires adequate and reliable methods. The present study aims to address this question with respect to medieval arrow trauma.

While prehistoric lithic projectile trauma is most often recognised as flint fragments embedded in bone, or arrowheads found in close association with remains (Lambert, 1997; Smith et al., 2007), medieval trauma analysis is almost exclusively based on wound morphology, except in rare circumstances such as that from Wisby in Sweden, where the preservation of metal artefacts was exceptional (Ingelmark, 1939; Thordeman, 1939: 124). Interpreting skeletal injuries based on wound morphology is not always straightforward, and it requires a great deal of both experience and research to be able to distinguish between different classes of trauma (Ubelaker and Montaperto, 2014). Rigorous experiments offer the potential for developing and improving recognition. While there has been much focus in recent years on the impact on bone made by different types prehistoric projectiles of stone, antler and bone (see Section 1.3. Previous experimental work), equivalent experiments focusing on impact marks made by medieval arrow points are lacking. Therefore, experimental recreation of medieval arrow trauma on bone is the focus of this article.

\subsection{Background}

The only surviving European longbows contemporary for their use in war are from the postmedieval wreckage of the Mary Rose from 1545 (Hardy, 1992: 54), which makes absolute statements about the exact nature of medieval longbows questionable. Based on finds and depictions, a little more is known about medieval arrowheads, which were of two main types: the broadhead, which could have barbs and was used both for hunting and war, and the bodkin, made specifically for warfare due to its armour-piercing abilities. An intermediate type combining features of both (Type 16) was also common (Loades, 2013: 24-25; Waller, 2007). Although archaeological finds show that arrowheads varied greatly in size and shape, making the existence of clearly defined types and sub-types questionable, a provisional typology established by Ward-Perkins (1940) for medieval English arrowheads is still widely used today, with a recent attempt at updating it (Jessop, 1996). Medieval projectile injuries from crossbows or longbows have mostly been recognised at sites with skeletal remains displaying remarkable numbers of peri-mortem weapon-related trauma, such as the mass graves from the 1461 Battle of Towton (Novak, 2007a, 2007b) and 1361 Battle of Wisby (Thordeman, 1939). A survey of nine medieval European sites revealed that projectile injuries made up about $10 \%$ of all recognised injuries and were much more prevalent on the cranium than the postcranial skeleton (Table 1). The largest number came from the Wisby remains, which had 127 cases of projectile injuries registered by Ingelmark (1939), whereas the Towton remains only had two certain projectile injuries (Novak, 2007a), or according to a recent re-evaluation, none (Holst and Sutherland, 2014), and four sites had no recognised or possible projectile injuries at all (Bennike, 2006; Giuffra et al., 2013; Kjellström, 2005; Šlaus et al., 2010). The survey revealed a lack of consensus in whether or not to attempt to distinguish between projectile injuries and other types of penetrating trauma. All punctures, sometimes referred to as penetrating injuries, were therefore counted as likely or potential projectile injuries at Wisby (Ingelmark, 1939) and Aljubarrota (Cunha and Silva, 1997; 
Cunha et al., 2001; Fernández et al., 2015). At Towton, puncture wounds were classified based on the insertion of different types of weapons and arrowheads into acoustic ceiling tiles to create profiles, which were then compared to the shape of the lesions (Novak, 2007a). This led to only two of 12 puncture wounds being classified as projectile trauma. The study by Novak (2007a) has been influential and used by others (Giuffra et al., 2013) when classifying medieval wounds. However, no details of the experiment were published, and no reasons given for using ceiling tiles as a proxy for human bone. It is apparent that amore controlled experimental approach to reproduce the effect of medieval arrows on bone is due if the identification of different types of medieval arrow trauma is to be more frequent as well as consistent.

\subsection{Previous experimental work}

Several studies have examined the performance of different types of modern and historical bows, often focusing on their physical properties such as velocity and ability to penetrate different tissues (Bergman et al., 1988; Karger et al., 1998; Kooi and Bergman, 1997; Miller et al., 1986; Pope, 1923). Archery experiments with a more narrow medieval focus are primarily concerned with the penetration effectiveness of various medieval arrow on different types of armour (Bane, 2006; Jones, 2014) and textiles (Jones, 2012) as part of an ongoing debate about the effectiveness of the longbow (Bourke and Whetham, 2007; Loades, 2013: 70-74). Some also look at the material composition of medieval arrowheads themselves (Ashkenazi et al., 2013; Starley, 2005). However, for the purposes of this study, it is the morphology of the bony lesions resulting from projectile impacts that are of. Recent years have seen several experiments focusing on the marks made on bone by prehistoric projectiles from bows and spearthrowers, with arrowheads made of stone (Castel, 2008; O'Driscoll and Thompson, 2014; Smith et al., 2007; Yeshurun and Yaroshevich, 2014), antler (Letourneux and Pétillon, 2008), and composite materials (Pétillon et al., 2011). Although these mostly focus on a prehistoric, zooarchaeological perspective, there are no similar studies on medieval projectile impacts, and so these experiments provide the only available comparable experimental data for the present article. A comparison of the above experiments reveals a lack of consensus about how to describe and classify the injuries, which has led to many different terms and categories being used by different authors. Some of the terms used to describe the damage are notches (Letourneux and Pétillon, 2008; Pétillon et al., 2011; Yeshurun and Yaroshevich, 2014), striations (Yeshurun and Yaroshevich, 2014), cuts, crushing (Castel, 2008; Pétillon et al., 2011) scraping, splitting, dislocation (Castel, 2008), punctures and perforations (Castel, 2008; Letourneux and Pétillon, 2008; Pétillon et al., 2011), "penetration holes" (Yeshurun and Yaroshevich, 2014) or "full thickness punctures" (Smith et al., 2007), cracking (Castel, 2008; Letourneux and Pétillon, 2008) and embedded (or implantation of) a point or point fragments (Castel, 2008; Letourneux and Pétillon, 2008; Smith et al., 2007). Smith et al. (2007) also observed internal bevelling on some of the experimentally produced defects, a type of damage characteristic of cranial entrance wounds from gunshots, where a projectile impact results in a defect that is larger internally than externally (Berryman and Symes, 1998; Quatrehomme and İşcan, 1998, 1999). The ratio between internal and external defect area was found to be significantly larger for lithic 
projectile impacts than gunshot lesions (Smith et al., 2007). O'Driscoll and Thompson (2014) recognised the need for a standardised method in order to make the results of different projectile experiments comparable. After surveying the terminology and findings of previous projectile impact studies and conducting their own experiments, they devised a simplified but comprehensive classification system with primary and secondary traits, which was used in an adapted and expanded version in the experiment described below (see Section 2.3, Data collection and analysis).

\subsection{Aims}

The following experimental study was conducted in order to improve the recognition of projectile trauma in medieval archaeological contexts, where analysis is based primarily on wound morphology. In order to achieve this, the main aim of the study was to examine and categorise the overall morphology and dimensions of bony lesions left by three different types of medieval arrowheads when fired into cattle scapulae, which were used as a proxy for human bone. A further aim was to examine if each of the three different types of medieval arrows would leave lesions different enough to be distinguishable from one another based on wound shape and size, as this would enable researchers to infer not only that a trauma was caused by a projectile but also which arrow was used, potentially providing valuable insight into the details of medieval warfare. It was also an aim to assess whether the experimental bony lesions made by medieval arrows were consistent with published cases of suspected medieval arrow trauma and if the data could be used to identify injuries previously ascribed to other types of force as potential arrow wounds.

\section{Materials and methods}

\subsection{Materials}

Ten each of the following three different types of replica arrowheads were used for the experiment (Fig. 1):

A: A broadhead with angular blades, similar to Type 1 from the London Museum catalogue (Ward-Perkins, 1940: 68) and Jessop type MP3, the latter classifying it as a multi purpose head, used for both hunting and war throughout the medieval period, from the 10th-16th century (Jessop, 1996). It will be referred to in the following as "broadhead".

B: A bodkin with a medium long blade and large socket. This is closest to London Type 8 (Ward-Perkins, 1940: 69-70) or Jessop military types M8/M9, and was an arrow-piercing head used only for warfare, with finds dating from the 13th-15th centuries (Jessop, 1996). It is referred to in the following as "bodkin".

C: A barbed broadhead of curved, swallowtail design, similar to London Type 14 (WardPerkins, 1940: 70) and Jessop hunting type H3 (Jessop, 1996). It has sharply cutting edges and would have been used mainly for hunting, as the barbs insure maximum tissue damageand bleeding (Ward-Perkins, 1940: 70; Loades, 2013, 25). Finds date to the 13th-15th centuries (Jessop, 1996;Ward-Perkins, 1940: 67-68). It is referred to in the following as "barbed broadhead". 
Prior to the experiment, the heads were all weighed and measured using digital scales and callipers, and photographed with a digital camera (Table 2).

The heads were chosen because their shapes and other properties were considered different enough that they could be expected to leave significantly different marks on bone, as well as representing the main types of medieval arrowheads. The broadheads and bodkins were partly machine-made but hand-finished, while the barbed broadheads were completely handforged by a blacksmith. All heads were made from mild steel. Real medieval arrowheads varied in material composition and could be made from iron, steel or a combination of the two (Jones, 2014; Starley, 2005). For the current study mild steel was considered adequate, as it has a hardness similar to hard iron used from the Early Middle Ages (Jones, 2012).

The shafts used were made from ash and fletched with plastic vanes, and had modern field tips attached. The shafts had an average length of $717 \mathrm{~mm}$ from nock to just below the tip, a diameter of $7.94 \mathrm{~mm}$, and a mass of $34.34 \mathrm{~g}$ (including the field-tip). As there were 30 heads for the experiment, but only 8 shafts available, the replica arrowheads were fastened on top of the modern tips using electrical tape so that the heads could be quickly changed and replaced during the experiment. One shaft had no field tip beforehand and two others lost the tips during the first phase of the experiment. These were sharpened with a pencil sharpener and heads then attached directly onto the shaft, meaning three of the arrows used were somewhat lighter than the others.

The longbow used for the present study was the same as the one used by Smith et al. (2007, 2011): a self bow made from a single stave of yew with a D-shaped profile, a design used throughout prehistory and the Middle Ages (Smith et al., 2011). At an estimated draw weight of approximately $18 \mathrm{~kg}(40 \mathrm{lb})$, it was much less powerful than the archaeological specimens from the Mary Rose, which had an estimated draw weight of $45.5 \mathrm{~kg}$ (100 lb) to $78 \mathrm{~kg}$ (172 lb) (Stirland, 2005:126). It was also somewhat less powerful than bows used in other experiments (Table 3), but the range was found to compare adequately to the bows used by Bergman et al. (1988) and Karger et al. (1998) when tested with field-tipped arrows (Smith et al., 2007).

15 domestic cattle (Bos Taurus) scapulae were obtained from two butchers. Bovine scapulae were considered an acceptable substitute for the human flat bones of the cranium, as they react in approximately the same manner when ballistic force is applied (Northern Ireland Office, 2002: 92) and have been used in a similar archery experiment (Smith et al., 2007). However, it must be noted that the cattle scapula are not an ideal proxy for human cranial bones as they differ from these in many aspects such as shape, density and lack of diploe. The projectile impacts in this study also have a much lower velocity than a bullet and this means that these differences are likely to affect the experimental outcome to a larger degree. Due to practical constraints, the bones were defleshed before shooting, using warm water and a detergent containing enzymes. This meant that no soft tissue was present when the boneswere impacted. However, the focus of the present study was the lesions left on the bone, and as the human skull does not have a thick layer of flesh, and medieval arrows have proven quite effective in penetrating soft tissues (Karger et al., 1998) and armour (Bane, 2006; Bourke and 
Whetham, 2007), the potential effect of soft tissue was considered negligible. It is also unlikely that recently defleshed bones will have significantly different response to stress, as bone can retain the properties and fracture patterns of fresh bone for several months (Wieberg and Wescott, 2008).

\subsection{Experiment}

For safety purposes, the arrows were fired at close range into a pit with a thick layer of loose sand at the bottom. Due to this setup, the bow was angled downwards and the scapulae were placed lateral side up one at a time on a raised platform of sand to approximate a perpendicular impact angle (Fig. 2). The shooting distance was approximately $2.25 \mathrm{~m}$ from bow to scapula. Five scapulae were used for each of the three types of arrows, and each bone was shot until it had at least three impact marks but no more than four, to avoid hitting the same spot twice. The lateral surface was targeted for all impacts. Arrowheads and arrows that missed were reused when they were in suitable condition, i.e. unbent and still sharply pointed. Shafts that split were sharpened and reused when possible until there were at least 15 impacts made by each type of arrow. Each of the 30 arrowheads was used at least once, and the order of the impacts made on bone was noted during the experiment.

\subsection{Data collection and analysis}

The marks were large enough to be mainly analysed with the naked eye and low magnification using a hand lens (10x). As a further aid a desktop visualizer was used (WolfVision VZ-8plus-3), which allowed the magnified marks to be observed on a monitor. Only in a few cases was further examination under a light microscope (10-80x) deemed necessary. This type of analysis has the benefit of being easy to duplicate as it does not require extensive use of expensive equipment, and it has been found adequate in the examination of sword and cutmarks (Lewis, 2008).More advanced techniques such as SEM are not always necessary for reliable interpretation of small marks (Blumenschine et al., 1996).

The marks were each given both a general morphological description as well as a detailed registration of specific traits based on the simplified classification system developed by O'Driscoll and Thompson (2014) for recording prehistoric projectile impact marks.

According to this, each impact was assigned to an overall category: puncture, drag, fracture, or a sub-category if a markwas a combination of one of the categories (i.e. puncture/fracture). A puncture indicates that the arrow has impacted the bone and gone partly or all the way through, a drag is a cut-like mark, and a fracture is recorded when the bone has been partially or completely fractured (O'Driscoll and Thompson, 2014). Secondary traits: length, shape, flaking, feathering, cracking, and breakage, were also scored according to O'Driscoll and Thompson (2014), who utilised the traits developed by Lewis (2008) for recording characteristics of sword marks, but found them useful and comprehensive for projectile impacts (see Supplementary data for details). Several observations were added: maximum width and maximum depth and bone thickness, an average of 3-5 measurements taken along the sides of the lesion. Puncture wounds were also subdivided into partial punctures and 
perforations, the latter indicating a complete puncture or hole through the bone (after Letourneux and Pétillon, 2008). For perforations, the characteristics of the "internal" wound on the opposite surface from the impact were also described and recorded, with special attention given to presence and size of bevelling.

Photos of each mark were imported into Adobe Photoshop CC to calculate the area of the external and,where applicable, internal defect (including bevelling), based on the scale in the photos and pixel count. Whilst clear differences were apparent in the size and shape of puncture defects in particular, it was necessary to then test whether the differences in the dimensions of defects caused by the different arrowheads were greater than would be expected to arise by chance. With regard to continuous variables (in this case the area of bevelling) a one-way ANOVA test was used as there were more than two samples being compared with a post-hoc test applied to identify the greatest sources of variance. Data that took the form of categories, for example whether or not each type of arrowhead produced flaking, could not be compared in this way and so were tested using Chi Square tests if all of the expected cell counts were N5, if not, Fisher's Exact Test was used. Statistical analysis was done using SPSS v. 22, and the chosen level of significance was 0.05. Data were checked to see if any of the assumptions of parametric testing had been violated. The data were checked for normal distribution with the Shapiro-Wilk test. If the normality assumption was not

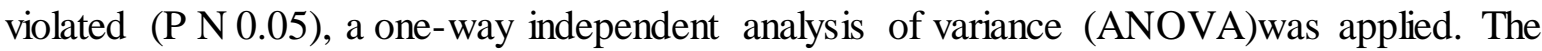
assumption of equal variances was tested with Levene's test, and if violated,Welch ANOVA was used instead. Post-hoc analyses were carried out if the ANOVA was significant $(\mathrm{P} \mathrm{b}$ 0.05), using either Tukey's HSD or Games-Howell, depending on whether or not the variances were equal. If the assumption of normality was violated, a Kruskal-Wallis H-test was used with Dunn's Bonferroni-adjusted post hoc tests.

\section{Results}

The experiment resulted in a total of 47 impact marks on bone, of which 17 (36.17\%) were made by broadheads and $15(31.91 \%)$ each by bodkins and barbed broadheads. In two cases the same impact left more than one trace (C9a-c and C12/13). These were only counted as one case (impact) each in the analysis.

\subsection{Lesion categories}

The vast majority of lesions (Table 4) were classified as punctures (40/47: 85.11\%; Fig. 3a), a few as fractures (4/47: 8.51\%; Fig. 3b), while only one was classified as a drag (1/47: $2.13 \%$; Fig. 3c), one as a puncture/fracture (1/47: 2.13\%), and one as a fracture/drag (1/47: $2.13 \%)$. The last category was not one of the three subcategories listed in the original method by O'Driscoll and Thompson (2014) but was added for this study. All lesions where the arrow hit the middle of the scapula perpendicularly or at a slight angle resulted in punctures of varying depth, and for all three types of arrows, punctures were by far the most common lesion. Lesions designated as fractures only occurred when the arrow missed the centre of the scapula, struck the edge of the bone or spine, and dislodged a small or large piece of bone. As such, all the marks here categorised as fractures also fit the "notch" category defined by 
Letourneux and Pétillon (2008). The barbed broadhead, which had very sharp edges, was the only type to leave cut-like drag marks, and only in two cases-in one (Fig. 3c) the arrow hit the bone at a tangent and skipped across the surface, leaving three shallow incised drag marks close together, and in the other, the arrow struck the scapular spine, tore off a piece of bone, and skimmed the surface of the scapula below.

\subsection{Penetration depth}

From a total of 40 punctures, $19(47.50 \%)$ were partial, while $21(52.50 \%)$ were perforations, where the whole or part of the arrowhead had gone through the bone. In three cases, one for each type of arrow, did the socket of the projectile penetrate as well. Broadheads and bodkins, in particular the bodkins, seemed to penetrate the bone more easily than the broader tip of the barbed broadheads, which were more likely to leave shallow marks when ricocheting across the bone surface. This also meant that the barbed broadheads did the most damage to the arrow shafts; all shafts had split transversely just below the point at the end of the experiment.

Partial punctures varied in depth from very shallow (b1 mm) to quite deep (N10 mm), and the maximum depths for bodkins $(10.90 \mathrm{~mm})$ and broadheads $(9.50 \mathrm{~mm})$ were roughly twice that of the barbed broadheads $(4.90 \mathrm{~mm})$. This discrepancy in penetrative capacity appeared to be backed up by the numerical data: the proportion of perforations was larger for punctures made by broadheads (8/14: $57.14 \%$ ) and bodkins (9/14: $64.29 \%)$ than for barbed broadheads (4/12: $33.33 \%)$, although a chi-square test revealed that this difference was not statistically significant $(\chi 2=2.669, \mathrm{df}=2, \mathrm{P}=0.263)$.

The average thickness of the scapula used for the experiments varied from $1 \mathrm{~mm}$ to $21 \mathrm{~mm}$ depending on the site of impact, with a mean of $6.44 \mathrm{~mm}$. The local thickness appeared to be an important factor in determining whether or not individual impacts penetrated the bone completely. The bone thickness at all perforations varied from $1 \mathrm{~mm}$ to $5.50 \mathrm{~mm}$, with the bone slightly thicker on average where is was perforated by the bodkins $(4.47 \mathrm{~mm})$ than where broadheads $(3.25 \mathrm{~mm})$ and barbed broadheads $(3.13 \mathrm{~mm})$ had caused perforations, indicating that bodkins were somewhat more likely to completely penetrate the bone. This difference was only just significant using a one-way ANOVA $(\mathrm{F}=3.654, \mathrm{df}=2,16$, $\mathrm{P}=0.049$ ), while post hoc Tukey's HSD comparisons between the individual head types showed no significance at the 0.05 level due to correcting for multiple comparisons and probably influenced by the unequal sample sizes.

\subsection{Wound shape}

The shape of each lesion was assessed and assigned the geometric shape that best described the outlines of the defect (Table 5), based on the list by O'Driscoll and Thompson (2014); see Supplementary data). In general the puncture wounds, which were the most numerous, had shapes that conformed more or less to the cross-section of the arrowhead used. The fractures and fracture subcategories were all described as amorphous and the few drags were linear or triangular. 
The most frequent shape of the broadhead lesions was an ellipse (7/17: 41.18\%; Fig. 4a), closely followed by a lozenge (5/17: 29.41\%; Fig.4b). It was often difficult to determine if the broadhead defect in each case most resembled a lozenge or an ellipse, which was expected given the rounded lozenge cross-section of the broadhead blade. Only in one case did a broadhead-tipped arrow completely penetrate the bone with both arrowblade and socket. The resulting shape was a rather large, slightly irregular elliptical shape (Fig. 4c). A few shallow lesions resulted in more triangular shapes.

The bodkin defects were the most consistently shaped, being mostly square (11/15: $73.33 \%$; Fig. 5a), conforming to the cross-section of the bodkin blade, and all the bodkin lesions were partly or fully quadrangular except in the case of a single fracture. When the arrow hit at a slight angle, it resulted in a rhombus-shaped defect instead of a square. One of the bodkins went through the bone with the whole head including the socket, which resulted in a roughly trapezial shape (Fig. 5b).

The most frequent shape for the barbed broadhead lesions was an ellipse (11/15: 73.33\%; Fig. $6 a)$, but the lesions were typically different from the elliptical shapes observed from the nonbarbed broadheads, in that they always tapered to narrow, very sharp points at the extremities due to the sharp edges on the head. In one case (Fig. 6b) the lesion shape resembled a spindle, or a circle in the middle of an ellipse, where the head and part of the socket had gone through. In one case (Fig. 6c) where thewhole barbed broadhead and socket went through, the result was a large ellipse with a large circular defect in the middle.

\subsection{Dimensions of punctures}

Only the dimensions of the lesions classified as punctures were used for comparative analysis, as these, unlike fractures and drags, corresponded to the actual shape of the arrowheads and therefore could be reasonably expected to vary predictably between arrow types, as well having dimensions that could be measured consistently. The dimensions of the puncture lesions (max. length, width, and area; Table 6) varied for the different types of arrows, with the puncture lesions made by bodkins being generally shorter and wider than the ones made by the other two types, corresponding to the differences in the arrowhead dimensions (Table 2), with the bodkin blade being approximately square compared to the more oblong cross-sections of the two broadhead types. The variation in length was significant (Kruskal-Wallis test: $\mathrm{H}=17.292$, df $=2, \mathrm{P}$ b 0.001), with post hoc Dunn's test showing that bodkin lesions were significantly shorter than barbed broadhead lesions $(\mathrm{P} \mathrm{b}$ 0.001), while the other comparisons were not significant after adjusting for multiple comparisons. Lesion width also varied significantly between types (Kruskal-Wallis test: $\mathrm{H}=15.542, \mathrm{df}=2, \mathrm{P}$ b 0.001), post hoc Dunn's test showing significant difference between bodkins and broadheads $(\mathrm{Q}=-15.429, \mathrm{P}=0.001)$ and bodkins and barbed broadheads $(\mathrm{Q}=15.095, \mathrm{P}=0.003)$. The areas of the lesions showed no significant variation between the different arrow types (Kruskal-Wallis test: $\mathrm{H}=1.195$, $\mathrm{df}=2, \mathrm{P}=0.550$ ). These results suggest that it is the shape of the lesions that differ between arrow types more than their overall size. 


\subsection{Secondary traits}

The summary results can be seen in Table 7. All fractures and fracture sub-categories had breakage, as pieces of bones has been torn off and lost during the experiment, and therefore fractures and the puncture/fracture could not be scored for flaking and feathering along the margins. No impacts had secondary radiating fractures (cracking). Of the 42 marks that could be scored, most had unilateral feathering (27/42: 64.29\%), some had bilateral feathering (10/42: $23.81 \%)$ while only few $(5 / 42: 11.90 \%)$ had no feathering. Flaking was much more rare (unilateral: 6/42: $14.29 \%$, bilateral: 4/42: 9.52\%). In five cases, both feathering and flaking were present on the same lesion, and only four lesions had no damage to the sides. Although flaking appeared to be slightly more frequent for barbed broadhead marks, there were no statistically significant differences in arrow type and the presence or state of either flaking or feathering (Table 8), likely in part due to the small sample size. There were, however, some qualitative differences in the damage seen on the margins of the different marks. The "feathers" of the broadhead marks were quite varied, sometimes very small and wispy, sometimes more like flakes or thin splinters (Fig. 7a). On the bodkin marks, feathers were generally larger and more flake-like (Fig. 7b). Some broadheads and bodkins had to be forcibly extracted prior to analysis after being embedded in the bone, which might have exacerbated the size of the feathers. The barbed broadhead lesions were generally more varied and showed more destruction, with ragged margins, likely cut by the sharp edges of the heads, and sometimes crushing damage to the sides (Fig. 7c). The few cut-like drag marks displayed unilateral feathering with a thin sheet of bone rolled up like a scroll along one side.

\subsection{Internal bevelling}

Bevelling was observed on the side opposite from impact or "internally" on nearly all perforations (Table 9; Fig. 8). In the following, the terms external and internal are used to refer to the defects on the lateral and medial surfaces of the scapula, respectively. This type of damage is typical of peri-mortem cranial injuries, where compressive forces from a penetrating weapon cause the tensile failure of the inner table, resulting in bony spalls (or flakes) of bone breaking off around the internal defect (Kimmerle and Baraybar, 2008: 291). Only two perforations produced no bevelling: in one case, only the outermost tip of the point had gone through the bone, and in the other, the bone was very thin $(1 \mathrm{~mm})$, which can make bevelling impossible (Quatrehomme and İscan, 1998). More than half of all the bevelled defects still had some or all of the bone spalls attached, although some of these were quite fragile and a few fell off during transport and analysis, making them unlikely to be preserved intact in an archaeological context. The bevelled areas were nearly always asymmetrical around the internal defect and had a variety of shapes. The ratio of internal to external area was calculated for all defects with internal bevelling, with the internal area including both bevelling and associated spalls when these were still attached (Table 10). The mean overall ratiowas 6.69, but individual values were quite variable, spanning from 2.04 to 38.20. The apparent differences between the ratios of the different arrow type lesions were not significant (Welch ANOVA: $\mathrm{F}=1.892$, $\mathrm{df}=2,4.59, \mathrm{P}=0.252$ ). 


\section{Discussion}

This experimental study shows that impacts by medieval projectiles on flat bones mostly result in puncture lesions of varying depth with well-defined shapes conformingmore or less to the profile of the arrowhead. Exceptions to this occur when the edge of the bone is hit, which results in fracture and bone wastage that does not differ between arrow types, or when a sharp-edged head like a barbed broadhead hits the bone at a tangent, which can result in very shallow, incision like marks.

These findings are consistent with the types of damage seen on flat bone in prehistoric projectile experiments (Letourneux and Pétillon, 2008; Pétillon et al., 2011; Yeshurun and Yaroshevich, 2014). There are some notable differences between marks left by broadheads, bodkins, and barbed broadheads (Table 11), the most important being the shape and dimensions of the puncture defects, which conform more or less to the cross-section and size of the arrowheads: roughly lozenge-shaped or elliptical defects for the lozenge broadhead, square defects for the bodkin, and narrow, sharply pointed ellipsoid-shaped defects for the barbed broadhead. The size of the individual lesion varies depending on how much of the point has penetrated the bone. In the few cases where the entire arrowhead and socket perforated the bone down to the shaft, it resulted in a larger defect similar to what was observed in Towton 40 (Novak, 2007a: 98).

The experimental results indicate that it is possible to distinguish between different types of arrows based on wound morphology, but only for puncture lesions, supporting the initial findings of the study reported by Novak (2007a). While it is easy to generally differentiate between puncture lesions made by bodkins and both kinds of broadheads, it may not always be possible to distinguish between different types of broadheads, especially considering the great variation seen in shapes of real medieval arrowheads.

The narrower bodkins and broadheads left deeper punctures than the barbed, curved broadheads, and especially the bodkins were more likely to penetrate the bone completely resulting in perforations, although this was not statistically significant. It is likely that a larger sample size could confirm these findings, as they are consistent with the design of the arrowheads themselves: the heavier bodkin was designed to pierce hard materials like armour, and the lozenge-shaped broadhead was a general purpose head, where the barbed broadhead with cutting edges was primarily meant for hunting and to cause maximum damage to soft tissue, resulting in bleeding - hitting bone in a hunting situation would likely be accidental (Loades, 2013: 24-35; Ward-Perkins, 1940: 65-70). The bodkins used were also the heaviest heads in this experiment $(\mathrm{N} 20 \mathrm{~g})$, and the barbed heads the lightest (b10 g), resulting in higher relative impact energy for the bodkins, which supports previous findings where only heavier prehistoric arrowheads (N10 g) completely punctured bone (Smith et al., 2007).

Besides the type of arrow used, the thickness at the impact site was a determining factor in whether or not individual arrows perforated the bone, as it varied greatly across the bones used for the experiment (1-21 mm,mean: 6.44). However, there is also great variation in the 
thickness throughout the bones of the human cranium. A similar overall mean thickness has been found in other studies. Overall mean thickness based on thickness at four cranial sites for male and females can be calculated to $6.29 \mathrm{~mm}$ based on the thickness at four cranial sites for both males and females (Lynnerup, 2001). Based on the results of Todd (1924), the overall mean thickness for male white crania is $6.63 \mathrm{~mm}$ calculated from the mean thickness at four cranial sites. This means that it is reasonable to expect the observed variation of puncture depth seen here mirrored in historic skeletal populations bearing signs of cranial projectile trauma. However, there are important differences in the shape and density of human crania and bovine scapulae which should not be ignored.

Another important observation is that the perforations made by the medieval arrowheads nearly always had internal bevelling, similar to prehistoric projectile wounds (Smith et al., 2007). The mean overall ratio of internal to external area of the bevelled defects was 6.69 $(\mathrm{n}=19)$, slightly lower than the $8.1(\mathrm{n}=7)$ reported for lithic projectiles by Smith et al. (2007), but the mean ratio varied between medieval arrowtypes: broadheads (3.88), bodkins (5.91), and barbed broadheads (15.59), although the differencewas not statistically significant. In spite of this variation, the mean ratios are all higher than the average $2.30(\mathrm{n}=$ 38) for gunshot entrance wounds with bevelling reported by Quatrehomme and İşcan (1998). This would seem to confirm the assertion made by Smith et al. (2007) that there are notable differences between arrow and gunshot trauma.

Not many medieval examples of potential broadhead lesions are published in sufficient detail to be of use in assessing to what extent the results of this experiment can be of use in real cases. There are three examples of suggested arrow trauma from the Fishergate site in York which seem consistent with the experimental broadhead lesions (Stroud and Kemp, 1993: 233, Fig. 71-72). Two are of roughly lozenge shape and could be from a non-barbed head, but the third is more consistent with a barbed head due to the sharp incisions at either end of the defect.

There are more published examples of potential bodkin lesions, possibly because the quadrangular defects with internal bevelling are easily recognisable as penetrating weapon trauma (i.e. Brødholt and Holck, 2012; Facchini et al., 2008; Ingelmark, 1939; Novak, 2007a or 2007b). The perforations on crania observed at Wisby by Ingelmark (1939) bear a strong resemblance to the experimental bodkin lesions, although some of these are more lozengeshaped than square. However, many medieval bodkins varied in cross-sectional shape from square or rhombus to a more lozenge-shaped (Ward-Perkins, 1940: 69, Fig. 17), which was also attested at Wisby (Thordeman, 1939: 134, Fig. 134), and Ingelmark (1939) based trauma analysis on these finds. This illustrates that wound analysis requires knowledge of the shape of different types of arrows in use at any given site,making attention to the archaeological context very important.

Only one lesion from Towton was classified as a bodkin lesion by Novak (2007a, 2007b), but some of the other published defects from the site are strikingly similar in size and shape to the experimental bodkin lesions (Novak, 2007a: 99, Fig. 8.11), while a few others are square but larger, all with internal bevelling. According to Novak (2007a) the larger defects could 
have been made by large crossbow bolts but are more likely to be from blunt force, while the smaller ones were ascribed to a poleaxe spike based on comparison with weapon impressions in ceiling tiles. Though most arrowheads from the Towton battlefield have a different crosssectional shape (Holst and Sutherland, 2014), some classical square or lozenge-shaped bodkins have been found there (Sutherland, 2007: 162, Fig. 14.11). Novak (2007a) argues that lesions without extensive radiating fractures are unlikely to be from "high velocity" crossbow trauma as a reason for why the larger lesions are most likely from blunt force. This argument was repeated by Giuffra et al. (2013) to support the notion that similar square lesions of variable size were likely from blunt force weapons and not projectile injuries, along with the argument that since there was only internal bevelling, and no exit wound, projectile injury was unlikely (Giuffra et al., 2013:Figs. 6b, 8a).

In the present experiment, however, only one bodkin completely penetrated the bone with the socket. For the rest of the perforations, only part of the point penetrated to the other side, which means that it is possible, and according to this study, common, for bodkins to leave square lesions with internal bevelling and no exit wound, although this is probably highly dependent on the power of the bow used. None of the experimental bodkin lesions showed secondary radiating fractures, which are often associated with high velocity gunshot injuries of the cranial vault in a modern, forensic context (Kimmerle and Baraybar, 2008: 330-331). This is not, in itself, evidence that the above-mentioned lesions could be arrow trauma, as these fractures are a response to increased intracranial pressure from the release of the kinetic energy of a bullet into the surrounding brain tissue (Berryman and Symes, 1998), which would not happen in a straight flat bone like a scapula, but require an enclosed space filled with soft tissue. Further, the longbow used for the current study was not very powerful compared to a crossbow. However, even a crossbow is not a high velocity weapon, and as demonstrated by Smith et al. (2015) a crossbow with a velocity of $75 \mathrm{~m} / \mathrm{s}$ will not produce radiating fractures when fired at spheres of simulated bone filled with ballistic gelatin, whereas high velocity projectiles (bullets) will (Smith et al., 2015). Therefore, the authors suggest that the experimental results demonstrate that bodkins can indeed leave small, square lesions very similar to those potentially produced by the spikes of poleaxes and beaks of warhammers, and it is not straightforward to distinguish between these, which Ingelmark (1939) had already concluded based on his study at Wisby. The results also suggest that the projectile wounds with associated radiating fractures which have been observed in other studies must have been the results of arrows fired at significantly higher velocity and/or with heavier points.

Investigations into medieval arrow trauma would involve experiments designed to investigate bony impacts made by other types of medieval weapons, such as war hammers and poleaxes as well as arrows, to see if it is possible to distinguish between projectile and other kinds of penetrating injuries.

This study has several limitations. Primarily, the differences between human cranial bone and bovine scapulae especially in density is a problem, as differences in structure and biomechanical properties are likely to influence the fractures resulting from low velocity projectile trauma to some degree. This is an important caveat to bear in mind if using the 
results from this experiment to interpret penetrative trauma in human skeletal remains. Another major limitation of this study is the fact that this experiment was performed in a static setting with an impact angle of approximately $90^{\circ}$ and with the arrows fired at very close range. This does not emulate an actual battle situation, as the arrows would be shot from long range and hit moving targets from above. This is an inherent problem with a controlled experiment like this, as it is impossible to account for all the different variables. Further, the fact that only scapulae were used is a limitation, as it has been demonstrated that projectiles leave other types of damage on long bones when compared with those on flat bones (Letourneux and Pétillon, 2008) as well as on spheres (Smith et al., 2015). In future experiments, it would be useful to have different types of bone as targets and also to shoot spheres of synthetic bone in order to have a more appropriate proxy for human bone and make recognition of both cranial and postcranial projectile trauma more consistent. It would also be valuable to have a larger sample size, a greater number of arrow types and a more powerful bow in order to assess the true variation of bony medieval arrow trauma. Lastly, examples of suspected medieval arrow trauma would need to be examined in person and not based on published material to determine if the experimental results are applicable to real cases.

\section{Conclusions}

This study provides insight into the defects different types of medieval arrowheads leave on flat bones. The lesions are almost all punctures and their shape roughly conforms to the crosssectional shape of the arrowhead used, meaning that broadheads will leave oblong, slit-like lesions, which are either elliptical or lozenge-shaped, while an armour-piercing bodkin results in quadrangular lesions. Barbed broadheads leave oblong, elliptical lesions similar to those produced by non-barbed heads, but the defects also tend to have sharply pointed extremities due to the sharply cutting edges of the point. The bodkin head appeared to be more efficient in perforating bone than were the broadheads, but this difference was not statistically significant. Confirmation of this observation requires larger samples sizes. Nearly all lesions that perforate the bone show internal bevelling, generally more extensive than that observed in gunshot wounds, and similar to that observed with lithic projectile defects. It appears that arrows can leave defects similar in morphology to lesions which have previously been ascribed to blunt force trauma. However, further studies on medieval lesions and experiments focusing on different types of medieval weapons are needed to determine if projectile trauma can be distinguished from other types of penetrating trauma. There is also a case to be made for reassessing some previously analysed assemblages exhibiting medieval battle trauma in order to consider the extent to which some wounds previously attributed to either penetrating hand to-hand weapons or projectiles might merit reclassification.

\section{Acknowledgements}

This project was funded by Bournemouth University. The authors would like to thank Stephen James and Cansu Kurt for assisting on the day of the experiment, as well as Giles Sturdy for kindly allowing the use of his land for the experiment. We are also grateful to blacksmith Alec Jones for making the barbed broadheads, and Stephen Griffths for procuring 
the broadheads and bodkins.We would also like to acknowledge F. Conisbee and Sons and Johannesminde for providing the scapulae used in the experiment, and Damian Evans and Mike Rowley at Bournemouth University for assisting in the laboratory during the defleshing process.

\section{Appendix A. Supplementary data}

Supplementary data to this article can be found online at http://dx.doi.org/10.1016/j.jasrep.2016.12.013 .

\section{References}

Ashkenazi, D., Golan, O., Tal, O., 2013. An archaeometallurgical study of 13th-century arrowheads and bolts from the crusader castle of Arsuf/Arsur. Archaeometry 55, 235-257.

Bane, M., 2006. English Longbow Testing Against Various armour ca. 1400. (Thesis available from: http://www.currentmiddleages.org/artsci/docs/Champ_Bane_ArcheryTesting.pdf [Accessed 8 September 2015]).

Bennike, P., 2006. Rebellion, combat, and massacre. A medieval mass grave at Sandbjerg near Næstved in Denmark. In: Otto, T., Thrane, H., Vandkilde, H. (Eds.), Warfare and Society. Archaeological and Anthropological Perspectives. Aarhus University Press, Aarhus, pp. 305-318.

Bergman, C.A., McEwen, E., Miller, R., 1988. Experimental archery: projectile velocities and comparison of bow performances. Antiquity 62, 658-670.

Berryman, H.E., Symes, S.A., 1998. Recognizing gunshot and blunt cranial trauma through fracture interpretations. In: Reichs, K.J. (Ed.), Forensic Osteology: Advances in the Identification of Human Remains. Charles Thomas, Springfield (IL), pp. 333-352.

Bill, J.H., 1862. Notes on arrow wounds. Am. J. Med. Sci. 44, 365-387.

Blumenschine, R.J., Marean, C.W., Capaldo, S.D., 1996. Blind tests of interanalyst correspondence and accuracy in the identification of cutmarks, percussion marks, and carnivore tooth marks on bone surfaces. J. Archaeol. Sci. 23, 493-507.

Bourke, P.,Whetham, D., 2007. A Report of the Findings of the Defence Academy Warbow Trials Part 1 Summer 2005. 4. Arms \& Armour, pp. 53-81.

Boylston, A., 2000. Evidence for weapon-related trauma in British archaeological samples. In: Cox, M., Mays, S. (Eds.), Human Osteology in Archaeology and Forensic Science. Cambridge University Press, Cambridge, pp. 357-380. 
Brødholt, E.T., Holck, P., 2012. Skeletal trauma in the burials from the royal church of St. Mary in medieval Oslo. Int. J. Osteoarchaeol. 22, 201-218.

Castel, J.C., 2008. Identification des impacts de projectiles surle squelette des grands ongulés. Ann. Paléontol. 94, 103-118.

Cunha, E., Silva, A.M., 1997. War lesions from the famous Portuguese medieval Battle of Aljubarrota. Int. J. Osteoarchaeol. 7, 595-599.

Cunha, E., Marques, C., Matos, V., 2001. In: Monteiro, J. (Ed.), Os mais verdadeiros testemunhos da Batalha de Aljubarrota: os ossos dos seus combatentes. Aljubarrota Revisitada, Imprensa da Universidade Coimbra, Coimbra, pp. 133-192.

Facchini, F., Rastelli, E., Belcastro, M.G., 2008. Peri mortem cranial injuries from a medieval grave in Saint Peter's Cathedral, Bologna, Italy. Int. J. Osteoarchaeol. 18, 421-430.

Fernández, A.P., Alemán, I., Botella, M.C., Cunha, E., 2015. Perimortem fractures in the osteological collection of Aljubarrota (Portugal). J. Anthropol. Archaeol. 40, 82-88.

Giuffra, V., Baricco, L.P., Subbrizio, M.P., Fornaciari, G., 2013. Weapon—related cranial lesions from medieval and renaissance Turin, Italy. Int. J. Osteoarchaeol. 25, 690-700.

Hardy, R., 1992. Longbow. A Social and Military History. Patrick Stephens Limited, Sparkford.

Holst, M.R., Sutherland, T.L., 2014. Towton revisited-analysis of the human remains from the Battle of Towton 1461. In: Eickhoff, S., Schopper, F. (Eds.), Forschungen zum Archäologie im Land Brandenburg Band 15, Schlachtfeld und Massengrab. Spektren interdisciplinärrer Auswertung von Orten der Gewalt. Brandenbürgisches Landesamt für Denkmalpflege, Wünsdorf, pp. 97-129.

Ingelmark, B.E., 1939. The skeletons. In: Thordeman, B. (Ed.), Armour from the Battle of Wisby 1361 I. Almqvist \& Wiksells Boktryckeri-A.-B., Uppsala, pp. 149-209.

Jessop, O., 1996. Artefact typology for the study of medieval arrowheads. Mediev. Archaeol. 40, 192-205.

Jones, D., 2012. Arrows against linen and leather armour. J. Soc. Archer-Antiqu. 55, 74-81.

Jones, D., 2014. Arrows against mail armour. J. Soc. Archer-Antiqu. 57, 62-70.

Karger, B., Sudhues, H., Kneubuehl, B.P., Brinkmann, B., 1998. Experimental arrow wounds: ballistics and traumatology. J. Trauma 45, 495-501.

Kimmerle, E.H., Baraybar, J.P., 2008. Skeletal Trauma. Identification of Injuries Resulting from Human Rights Abuse and Armed Conflict. CRC Press, Boca Raton (FL).

Kjellström, A., 2005. A sixteenth-century warrior grave from Uppsala, Sweden: the battle of Good Friday. Int. J. Osteoarchaeol. 15, 23-50. 
Knüsel, C.J., Smith, M.J., 2014. Introduction. The bioarchaeology of conflict. In: Knüsel, C., Smith, M.J. (Eds.), The Routledge Handbook of the Bioarchaeology of Human Conflict. Routledge, Oxon, pp. 3-14.

Kooi, B.W., Bergman, C.A., 1997. An approach to the study of ancient archery using mathematical modelling. Antiquity 71, 124-134.

Lambert, P.M., 1997. Patterns of violence in prehistoric hunter-gatherer societies of coastal southern California. In: Martin, D.L., Frayer, D.W. (Eds.), Troubled Times. Violence and Warfare in the Past. Gordon and Breach Publishers, New York, pp. 77-109.

Letourneux, C., Pétillon, J.-M., 2008. Hunting lesions caused by osseous projectile points: experimental results and archaeological implications. J. Archaeol. Sci. 35, 2849-2862.

Lewis, J.E., 2008. Identifying sword marks on bone: criteria for distinguishing between cut marks made by different classes of bladed weapons. J. Archaeol. Sci. 35, 2001-2008.

Loades, M., 2013. The Longbow. Osprey Publishing, Oxford.

Lynnerup, N., 2001. Cranial thickness in relation to age, sex and general body build in a Danish forensic sample. Forensic Sci. Int. 117, 45-51.

Miller, R., McEwen, E., Bergman, C., 1986. Experimental approaches to Near Eastern archery. World Archaeol. 18, 178-195.

Milner, G.R., 2005. Nineteenth-century arrow wounds and perceptions of prehistoric warfare. Am. Antiq. 70, 144-156.

Milner, G.R., Anderson, E., Smith, V.G., 1991. Warfare in prehistoric West-Central Illinois. Am. Antiq. 56, 581-603.

Northern Ireland Office, 2002. Patten Report Recommendations 69 and 70 Relating to Public Order Equipment. A Research Programme into Alternative Policing Approaches Towards the Management of Conflict. 3rd Report. Belfast: Northern Ireland Office, in Consultation With the Association of Chief Police Officers.

Novak, S.A., 2007a. Battle-related trauma. In: Fiorato, V., Boylston, A., Knüsel, C.J. (Eds.), Blood Red Roses. The Archaeology of a Mass Grave from the Battle of Towton AD 1461 (Second Revised Edition). Oxbow Books, Oxford, pp. 90-102.

Novak, S., 2007b. Case studies. In: Fiorato, V., Boylston, A., Knüsel, C.J. (Eds.), Blood Red Roses. The Archaeology of a Mass Grave From the Battle of Towton AD 1461 (Second Revised Edition). Oxbow Books, Oxford, pp. 240-268.

O'Driscoll, C.A., Thompson, J.C., 2014. Experimental projectilemarks on bone: implications for identifying the origins of projectile technology. J. Archaeol. Sci. 49, 398-413. 
Pétillon, J.-M., Bignon, O., Bodu, P., Cattelain, P., Debout, G., Langlais, M., Laroulandie, V., Plisson, H., Valentin, B., 2011. Hard core and cutting edge: experimental manufacture and use of Magdalenian composite projectile tips. J. Archaeol. Sci. 38, 1266-1283.

Pope, S.T., 1923. A Study of Bows and Arrows. 2011. University of California Press:

Berkeley. Fascimile, Mansfield Centre: Martino Publishing.

Quatrehomme, G., İşcan, M.Y., 1998. Analysis of bevelling in gunshot entrance wounds.

Forensic Sci. Int. 93, 45-60.

Quatrehomme, G., İşcan, M.Y., 1999. Characteristics of gunshot wounds in the skull. $J$. Forensic Sci. 44, 568-576.

Shea, J.J., 2006. The origins of lithic projectile point technology: evidence from Africa, the Levant, and Europe. J. Archaeol. Sci. 33, 823-846.

Šlaus, M., Novak, M., Vyroubal, V., Bedić, Ž., 2010. The harsh life on the 15th century Croatia- Ottoman Empire military border: analyzing and identifying the reasons for the massacre in Čepin. Am. J. Phys. Anthropol. 141, 358-372.

Smith, M.J., Brickley, M.B., Leach, S.L., 2007. Experimental evidence for lithic projectile injuries: improving identification of an under-recognised phenomenon. J. Archaeol. Sci. 34, 540-553.

Smith, M.J., Brickley, M.B., Leach, S., 2011. A shot in the dark? Interpreting evidence for prehistoric conflict. In: Saville, A. (Ed.), Flint and Stone in the Neolithic Period. Oxbow Books, Oxford, pp. 256-270.

Smith, M.J., James, S., Pover, T., Ball, N., Barnetson, V., Foster, B., Guy, C., Rickman, J., Walton, V., 2015. Fantastic plastic? Experimental evaluation of polyurethane bone substitutes as proxies for human bone in trauma simulations. Legal Med. 17, 427-435.

Starley, D., 2005. What's the Point? A metallurgical insight into medieval arrowheads. In: Bork, R. (Ed.), De Re Metallica. The Uses of Metal in the Middle Ages, AVISTA Studies in the History of Medieval Technology, Science and Art 4. Ashgate Press, Aldershot, pp. 207218.

Stirland, A.J., 2005. The Men of the Mary Rose. Raising the Dead. New Revised Edition. The History Press, Stroud.

Stroud, G., Kemp, R.L., 1993. Cemeteries of St. Andrew, Fishergate. The Archaeology of York 12 (2). The Council for British Archaeology, York.

Sutherland, T., 2007. The archaeological investigation of the Towton battlefield. In: Fiorato, V., Boylston, A., Knüsel, C. (Eds.), Blood Red Roses. The Archaeology of a Mass Grave from the Battle of Towton AD 1461 (Second Revised Edition). Oxbow Books, Oxford, pp. 155-168. 
Thordeman, B., 1939. Armour From the Battle of Wisby 1361. Vol. I Text. Almqvist \& Wiksells Boktryckeri-A.-B., Uppsala, pp. 149-209.

Todd, T.W., 1924. Thickness of the male white cranium. Anat. Rec. 27, 245-256. 


\section{Tables}

\section{Table 1}

Peri-mortem projectile injuries from selected medieval sites with individuals displaying peri-mortem weaponrelated trauma. MNI: minimum number of individuals at site. SFT: sharp force trauma. BFT: Blunt force trauma. Only peri-mortem trauma is included.

\begin{tabular}{|c|c|c|c|c|c|c|c|}
\hline $\begin{array}{l}\text { Site } \\
\text { Context } \\
\text { Date }\end{array}$ & $\overline{\mathrm{MNI}}$ & $\begin{array}{l}\text { Projectile } \\
\text { trauma/ } \\
\text { total } \\
\text { trauma } \\
n / N(\%)\end{array}$ & $\begin{array}{l}\text { Cranial }^{\text {a }} \\
\text { projectile } \\
\text { trauma/total } \\
\text { cranial } \\
\text { trauma } \\
n / N(\%)\end{array}$ & $\begin{array}{l}\text { Postcranial } \\
\text { projectile } \\
\text { trauma/total } \\
\text { postcranial } \\
\text { trauma } \\
n / N(\%)\end{array}$ & $\begin{array}{l}\text { Trauma } \\
\text { comments }\end{array}$ & $\begin{array}{l}\text { Projectile type } \\
\text { responsible for } \\
\text { lesion(s) }\end{array}$ & Reference \\
\hline $\begin{array}{l}\text { St. Nicholas } \\
\text { Shambles, } \\
\text { London } \\
\text { Cemetery } \\
\text { 11th-12th } \\
\text { centuries }\end{array}$ & 234 & $\begin{array}{l}1 / 3 \\
(33.33 \%)\end{array}$ & $\begin{array}{l}1 / 3 \\
(33.33 \%)\end{array}$ & $\begin{array}{l}0 / 0 \\
(0 \%)\end{array}$ & $\begin{array}{l}1 \text { "missile" } \\
\text { wound, } 1 \\
\text { puncture } \\
\text { wound, } 1 \mathrm{SFT}\end{array}$ & - & $\begin{array}{l}\text { White, } \\
1988\end{array}$ \\
\hline $\begin{array}{l}\text { Sandbjerget, } \\
\text { Denmark } \\
\text { Mass grave } \\
\text { Civil war } \\
\text { 1300-1350 }\end{array}$ & 60 & $0 / 185(0 \%)$ & $0 / 122(0 \%)$ & $0 / 63(0 \%)$ & All SFT & - & $\begin{array}{l}\text { Bennike, } \\
2006\end{array}$ \\
\hline $\begin{array}{l}\text { Wis by }{ }^{b}, \\
\text { Sweden } \\
1361 \\
\text { Mass grave } \\
\text { from battle }\end{array}$ & 1185 & $\begin{array}{l}127 / 700 \\
(18.14 \%)\end{array}$ & $\begin{array}{l}125 / 370 \\
(33.78 \%)\end{array}$ & $\begin{array}{l}2 / 330 \\
(0.61 \%)\end{array}$ & $\begin{array}{l}\text { All punctures } \\
\text { counted as } \\
\text { projectile } \\
\text { trauma }\end{array}$ & $\begin{array}{l}\text { Crossbow } \\
\text { arrows with } \\
\text { square cross- } \\
\text { section, based } \\
\text { on finds and } \\
\text { wound shape }\end{array}$ & $\begin{array}{l}\text { Ingelmark, } \\
1939 ; \\
\text { Thorde- } \\
\text { man, } 1939\end{array}$ \\
\hline $\begin{array}{l}\text { Aljubarrota, } \\
\text { Portugal } \\
\text { Mass grave } \\
\text { from battle } \\
1385\end{array}$ & 414 & $\begin{array}{l}14 / 110 \\
(12.73 \%)\end{array}$ & $\begin{array}{l}4 / 16 \\
(25 \%)\end{array}$ & $\begin{array}{l}10 / 94 \\
(10.64 \%)\end{array}$ & $\begin{array}{l}\text { Punctures not } \\
\text { ascribed to } \\
\text { specific } \\
\text { weapon } \\
\text { classes, all } \\
\text { potential } \\
\text { projectile } \\
\text { wounds }\end{array}$ & - & $\begin{array}{l}\text { Cunha and } \\
\text { Silva, } \\
\text { 1997; } \\
\text { Cunha et } \\
\text { al., 2001; } \\
\text { Fernández } \\
\text { et al., 2015 }\end{array}$ \\
\hline $\begin{array}{l}\text { Čepin, } \\
\text { Croatia } 1441 \\
\text { Cemetery } \\
\text { Akinji raid } \\
\text { victims }\end{array}$ & 147 & $\begin{array}{l}0 / 82 \\
(0 \%)\end{array}$ & $\begin{array}{l}0 / 36 \\
(0 \%)\end{array}$ & $\begin{array}{l}0 / 46 \\
(0 \%)\end{array}$ & $\begin{array}{l}\text { All SFT } \\
\text { except } 1 \\
\text { penetrating } \\
\text { wound (beak } \\
\text { of war } \\
\text { hammer?) }\end{array}$ & - & $\begin{array}{l}\text { Šlaus et } \\
a l ., 2010\end{array}$ \\
\hline $\begin{array}{l}\text { Turin, Italy } \\
\text { Cemetery } \\
\text { 10th-11th } \\
\text { centuries } \\
15 \text { th century }\end{array}$ & $4^{\mathrm{c}}$ & $\begin{array}{l}0 / 3(0 \%) \\
0 / 9(0 \%)\end{array}$ & $\begin{array}{l}0 / 3(0 \%) \\
0 / 9(0 \%)\end{array}$ & $\begin{array}{l}0 / 0(0 \%) \\
0 / 0(0 \%)\end{array}$ & $\begin{array}{l}3 \text { puncture } \\
\text { lesions, } \\
\text { potentially } \\
\text { projectile but } \\
\text { ascribed to } \\
\text { BFT }\end{array}$ & - & $\begin{array}{l}\text { Giuffra et } \\
\text { al., } 2013\end{array}$ \\
\hline
\end{tabular}




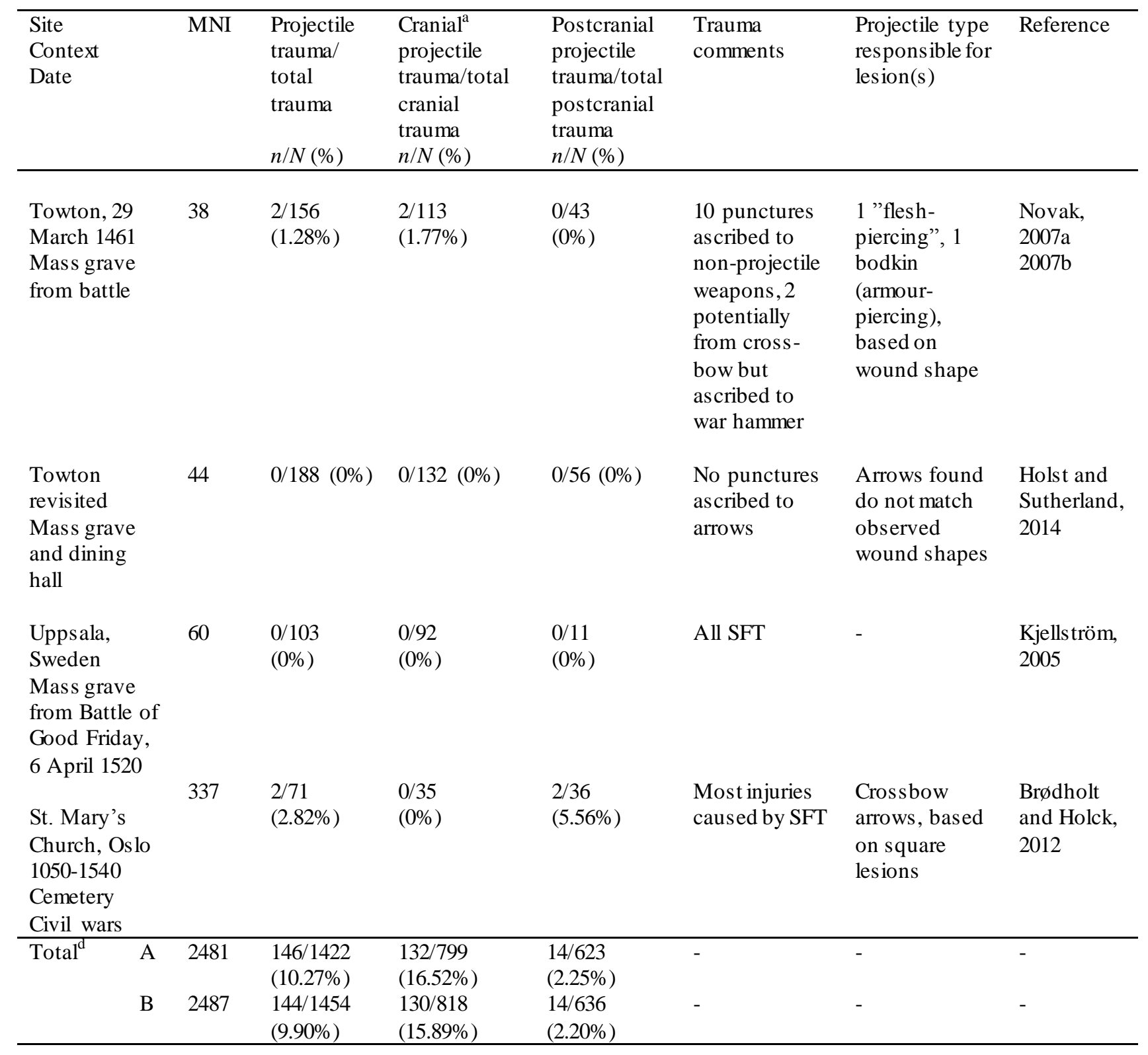

an this context the terms 'cranial' and 'postcranial' refer to injuries affecting the skull (i.e. cranium and mandible) and the rest of the skeleton from the cervical vertebrae downwards, respectively. In this regard we have used these terms to concord with common usage and have avoided the alternative term 'cephalic extremity', as this latter also includes the bones of neck.

${ }^{\mathrm{b}} \mathrm{W}$ is by: the numbers given indicate cases, i.e. numbers of skeletal elements or crania on which trauma of each type is present, and not an absolute count of the number of individual lesions on each element. The numbers are calculated based on Ingelmark (1939). One postcranial and five cranial cases of projectile trauma were based on arrowheads lodged in bone or inside the skull (Ingelmark, 1939; Thordeman, 1939: 124).

${ }^{\mathrm{c}}$ Individuals with injuries.

${ }^{\mathrm{d}}$ A: Towton revisited data excluded, B: original Towton data excluded. 
Table 2

Average dimensions, weights and cross-sections of the replica arrowheads used in the experiment.

\begin{tabular}{|c|c|c|c|c|}
\hline & & $\begin{array}{l}\text { Broadhead } \\
(N=10)\end{array}$ & $\begin{array}{l}\text { Bodkin } \\
(N=10)\end{array}$ & $\begin{array}{l}\text { Barbed broadhead } \\
(N=10)\end{array}$ \\
\hline \multirow{4}{*}{$\begin{array}{l}\text { Total length } \\
(\mathrm{mm})\end{array}$} & Mean & 74.22 & 88.38 & 43.01 \\
\hline & $\mathrm{SD}$ & 2.16 & 2.13 & 1.44 \\
\hline & Min. & 71.05 & 84.94 & 40.66 \\
\hline & Max. & 77.27 & 92.28 & 45.60 \\
\hline \multirow{4}{*}{$\begin{array}{l}\text { Blade length } \\
(\mathrm{mm})\end{array}$} & Mean & 51.93 & 32.43 & 14.15 \\
\hline & SD & 2.27 & 1.76 & 1.06 \\
\hline & Min. & 48.03 & 30.21 & 12.65 \\
\hline & Max. & 55.10 & 36.84 & 15.54 \\
\hline \multirow{4}{*}{$\begin{array}{l}\text { Max. width } \\
(\mathrm{mm})\end{array}$} & Mean & 16.90 & 9.75 & 14.15 \\
\hline & SD & 0.52 & 0.39 & 1.06 \\
\hline & Min. & 16.09 & 9.26 & 12.65 \\
\hline & Max. & 17.80 & 10.24 & 15.54 \\
\hline \multirow{4}{*}{$\begin{array}{l}\text { Blade max. thickness } \\
(\mathrm{mm})\end{array}$} & Mean & 5.50 & 9.77 & 2.85 \\
\hline & $\mathrm{SD}$ & 0.33 & 1.41 & 0.28 \\
\hline & Min. & 5.01 & 5.50 & 2.26 \\
\hline & Max. & 6.10 & 10.24 & 3.19 \\
\hline \multirow{4}{*}{$\begin{array}{l}\text { Socket max. } \\
\text { diameter } \\
(\mathrm{mm})\end{array}$} & Mean & 9.80 & 10.84 & 10.83 \\
\hline & SD & 0.57 & 0.50 & 0.46 \\
\hline & Min. & 9.48 & 9.84 & 10.18 \\
\hline & Max. & 10.95 & 11.77 & 11.65 \\
\hline \multirow{4}{*}{$\begin{array}{l}\text { Mass } \\
(\mathrm{g})\end{array}$} & Mean & 15.15 & 24.01 & 8.69 \\
\hline & SD & 1.84 & 1.54 & 0.97 \\
\hline & Min. & 13.19 & 22.23 & 7.19 \\
\hline & Max. & 18.79 & 26.14 & 10.18 \\
\hline \multirow[t]{3}{*}{$\begin{array}{l}\text { Cross-sectional } \\
\text { shape }\end{array}$} & Blade & $\begin{array}{l}\text { Lozenge } \\
\text { with }\end{array}$ & Square & $\begin{array}{l}\text { Ellipse with sharply } \\
\text { pointed ends }\end{array}$ \\
\hline & & $\begin{array}{l}\text { rounded } \\
\text { ends }\end{array}$ & & \\
\hline & Blade+socket & $\begin{array}{l}\text { Combination } \\
\text { of circle and } \\
\text { lozenge }\end{array}$ & Circle & $\begin{array}{l}\text { Combination of } \\
\text { circle and ellipse } \\
\text { with pointed ends }\end{array}$ \\
\hline
\end{tabular}

All dimensions are in millimeters. SD: standard deviation. Total length: maximum length of head, including socket. Blade length: length of head excluding socket. Max. width: maximum width, for barbed broadhead this includes barbs. Blade max. thickness: for barbed broadhead, which excludes the socket. Blade+socket indicates the cross-sectional shape of the arrow blade and socket combined. For bodkins, which have a square crosssection, the maximu m thickness and width are measured along the diagonals, not the sides of the square. 
Table 3

Statistics of the bow used for this study compared to other longbows used for similar experiments.

\begin{tabular}{lllll}
\hline Statistic & $\begin{array}{l}\text { This study/ } \\
\text { Smith } \text { et al., } \\
2007\end{array}$ & $\begin{array}{l}\text { Letourneux and } \\
\text { Pétillon, 2008 }\end{array}$ & $\begin{array}{l}\text { Karger } \text { et al., } \\
1998\end{array}$ & $\begin{array}{l}\text { Bergman } \text { et } \\
\text { al., 1988 }\end{array}$ \\
& Self bow & Self bow & Self bow & Self bow \\
Type & Yew & Yew & Yew & Yew \\
Material & $181 / 177.5^{\mathrm{a}}$ & 177 & - & 193 \\
Length $(\mathrm{cm})$ & 59 & 68.6 & 72.5 & 81.3 \\
Draw length $(\mathrm{cm})$ & Approx. $18 / 40^{\mathrm{b}}$ & $27.9 / 61.5$ & $23.6 / 52.5$ & $36.2 / 79.1$ \\
Draw weight $(\mathrm{kg} / \mathrm{lb})$ & & & & \\
\hline
\end{tabular}

${ }^{\mathrm{a}}$ Unstrung/strung length.

${ }^{\mathrm{b}}$ While previously thought to be $50 \mathrm{lbs}$ (Smith et al., 2007: Table 3), a re-evaluation of the bow has led to the downward adjustment of the estimated draw weight.

\section{Table 4}

Classification of all projectile lesions.

\begin{tabular}{lllll}
\hline Category & Broadhead & Bodkin & Barbed broadhead & Total \\
\hline Puncture & 14 & 14 & 12 & 40 \\
Fracture & 2 & 1 & 1 & 4 \\
Drag & 0 & 0 & 1 & 1 \\
Puncture/fracture & 1 & 0 & 0 & 1 \\
Fracture/drag & 0 & 0 & 1 & 1 \\
Total & 17 & 15 & 15 & 47 \\
\hline
\end{tabular}


Table 5

Summary of the shapes of the projectile impacts for the three arrow types.

\begin{tabular}{|c|c|c|c|c|c|c|c|c|c|c|c|}
\hline \multirow[t]{2}{*}{ Shape } & & \multicolumn{3}{|c|}{$\begin{array}{l}\text { Broadhead } \\
(n=17)\end{array}$} & \multicolumn{2}{|c|}{$\begin{array}{l}\text { Bodkin } \\
(n=15)\end{array}$} & \multicolumn{4}{|c|}{$\begin{array}{l}\text { Barbed broadhead } \\
(n=15)\end{array}$} & \multirow[t]{2}{*}{ Total } \\
\hline & & Punct & Fract & Other & Punct & Fract & Punct & Fract & Drag & Other & \\
\hline & Ellipse & 7 & 0 & 0 & 0 & 0 & 9 & 0 & 0 & 0 & 16 \\
\hline & Lozenge & 5 & 0 & 0 & 0 & 0 & 0 & 0 & 0 & 0 & 5 \\
\hline & Triangle & 2 & 0 & 0 & 0 & 0 & 0 & 0 & 0 & 0 & 2 \\
\hline & Square & 0 & 0 & 0 & 11 & 0 & 0 & 0 & 0 & 0 & 11 \\
\hline & Rhombus & 0 & 0 & 0 & 1 & 0 & 0 & 0 & 0 & 0 & 1 \\
\hline & Trapezium & 0 & 0 & 0 & 1 & 0 & 0 & 0 & 0 & 0 & 1 \\
\hline & Amorphous & 0 & 2 & 1 & 0 & 1 & 1 & 1 & 0 & 0 & 6 \\
\hline \multirow{2}{*}{$\begin{array}{l}\text { Merged } \\
\text { shapes }\end{array}$} & Square+ellipse & 0 & 0 & 0 & 1 & 0 & 0 & 0 & 0 & 0 & 1 \\
\hline & Circle+ellipse & 0 & 0 & 0 & 0 & 0 & 2 & 0 & 0 & 0 & 2 \\
\hline \multirow{2}{*}{$\begin{array}{l}\text { More than } \\
\text { one shape } \\
\text { separately }\end{array}$} & Triangle/lines & 0 & 0 & 0 & 0 & 0 & 0 & 0 & 1 & 0 & 1 \\
\hline & Amorphous/line & 0 & 0 & 0 & 0 & 0 & 0 & 0 & 0 & 1 & 1 \\
\hline \multicolumn{2}{|c|}{ Total number of lesions } & 14 & 2 & 1 & 14 & 1 & 12 & 1 & 1 & 1 & 47 \\
\hline
\end{tabular}


Table 6.

Descriptive statistics of the puncture lesions made by the three different arrow types.

\begin{tabular}{llllll}
\hline Measurement & & $\begin{array}{l}\text { Broadhead } \\
(n=14)\end{array}$ & $\begin{array}{l}\text { Bodkin } \\
(n=14)\end{array}$ & $\begin{array}{l}\text { Barbed broadhead } \\
(n=12)\end{array}$ & $\begin{array}{l}\text { All } \\
(n=40)\end{array}$ \\
\hline $\begin{array}{l}\text { Maximum length } \\
(\mathrm{mm})\end{array}$ & Mean & 10.34 & 6.76 & 14.89 & 10.45 \\
& Median & 9.33 & 5.86 & 12.20 & 9.33 \\
& SD & 4.49 & 2.40 & 6.77 & 5.71 \\
& Min. & 5.50 & 3.98 & 7.50 & 3.98 \\
& Max. & 21.93 & 13.24 & 30.75 & 30.75 \\
Maximum width & Mean & 3.36 & 6.18 & 4.01 & 4.54 \\
$($ mm) & Median & 2.79 & 5.49 & 2.80 & 3.47 \\
& SD & 2.15 & 1.88 & 3.26 & 2.70 \\
& Min. & 2.19 & 4.33 & 1.79 & 1.79 \\
& Max. & 10.70 & 10.20 & 12.74 & 12.74 \\
Area & & & & 33.54 \\
$\left(\mathrm{~mm}^{2}\right)$ & Mean & 30.74 & 26.96 & 44.49 & 18.94 \\
& Median & 18.00 & 17.93 & 24.24 & 41.30 \\
& SD & 40.40 & 24.04 & 56.86 & 9.28 \\
& Min. & 9.39 & 9.28 & 9.79 & 215.03 \\
\hline
\end{tabular}

Max. length and width for the roughly square bodkin defects were measured along the diagonals, not the sides.

Table 7

Summary of secondary traits recorded for the lesions made by the three types of arrowheads.

\begin{tabular}{|c|c|c|c|c|c|c|c|c|c|c|c|}
\hline \multirow[t]{2}{*}{ Trait } & \multirow[t]{2}{*}{ State } & \multicolumn{3}{|c|}{$\begin{array}{l}\text { Broadhead } \\
(n=17)\end{array}$} & \multicolumn{2}{|c|}{$\begin{array}{l}\text { Bodkin } \\
(n=15)\end{array}$} & \multicolumn{4}{|c|}{$\begin{array}{l}\text { Barbed broadhead } \\
(n=15)\end{array}$} & \multirow[t]{2}{*}{ Total } \\
\hline & & Punct & Fract & Other & Punct & Fract & Punct & Fract & Drag & Other & \\
\hline \multirow[t]{2}{*}{ Feathering } & Unilateral & 9 & $\mathrm{n} / \mathrm{a}$ & $\mathrm{n} / \mathrm{a}$ & 8 & $\mathrm{n} / \mathrm{a}$ & 7 & $\mathrm{n} / \mathrm{a}$ & 1 & 1 & 26 \\
\hline & Bilateral & 4 & $\mathrm{n} / \mathrm{a}$ & $\mathrm{n} / \mathrm{a}$ & 3 & $\mathrm{n} / \mathrm{a}$ & 2 & $\mathrm{n} / \mathrm{a}$ & 0 & 0 & 9 \\
\hline \multirow[t]{2}{*}{ Flaking } & Unilateral & 0 & $\mathrm{n} / \mathrm{a}$ & $\mathrm{n} / \mathrm{a}$ & 1 & $\mathrm{n} / \mathrm{a}$ & 4 & $\mathrm{n} / \mathrm{a}$ & 0 & 0 & 5 \\
\hline & Bilateral & 1 & $\mathrm{n} / \mathrm{a}$ & $\mathrm{n} / \mathrm{a}$ & 2 & $\mathrm{n} / \mathrm{a}$ & 1 & $\mathrm{n} / \mathrm{a}$ & 0 & 0 & 4 \\
\hline Cracking & & 0 & 0 & 0 & 0 & 0 & 0 & 0 & 0 & 0 & 0 \\
\hline Breakage & & 0 & 2 & 1 & 0 & 1 & 0 & 1 & 0 & 1 & 6 \\
\hline
\end{tabular}

Punct: puncture lesion; Fract: Fracture lesion; Other: Sub-categories. 


\section{Table 8}

Comparisons between secondary traits and arrow types, showing no significant difference in trait presence or state for any of the arrow types $(P>0.05)$.

\begin{tabular}{lllllllll}
\hline State & \multicolumn{3}{l}{ Broadhead } & Bodkin & \multicolumn{3}{l}{ Barbed broadhead } & \multicolumn{2}{l}{ Fisher's Exact test } \\
\cline { 2 - 10 } & Count & $n$ & Count & $n$ & Count & $n$ & $N$ & $P$-value \\
\hline $\begin{array}{l}\text { Feathering } \\
\text { present }\end{array}$ & 13 & 14 & 11 & 14 & 11 & 14 & 42 & 0.665 \\
$\begin{array}{l}\text { Unilateral } \\
\text { feathering }\end{array}$ & 9 & 13 & 8 & 11 & 9 & 12 & 36 & 0.798 \\
$\begin{array}{l}\text { Bilateral } \\
\text { feathering }\end{array}$ & 4 & 13 & 3 & 11 & 2 & 12 & 36 & 0.798 \\
$\begin{array}{l}\text { Flaking } \\
\text { present }\end{array}$ & 1 & 14 & 3 & 14 & 5 & 14 & 42 & 0.240 \\
$\begin{array}{l}\text { Unilateral } \\
\text { flaking }\end{array}$ & 0 & 1 & 1 & 3 & 4 & 5 & 9 & 0.286 \\
$\begin{array}{l}\text { Bilateral } \\
\text { flaking }\end{array}$ & 1 & 1 & 2 & 3 & 1 & 5 & 9 & 0.286 \\
\hline
\end{tabular}

Table 9

Internal bevelling of perforation defects.

\begin{tabular}{lllll}
\hline & Broadhead & Bodkin & Barbed broadhead & Total \\
\hline Bevelling present $^{\mathrm{a}}$ & $7 / 8(87.50 \%)$ & $9 / 9(100.00 \%)$ & $3 / 4(75.00 \%)$ & $19 / 21(90.48 \%)$ \\
Spalls attached $^{\mathrm{b}}$ & $4 / 7(57.14 \%)$ & $6 / 9(66.66 \%)$ & $2 / 3(66.66 \%)$ & $12 / 19(63.16 \%)$ \\
\hline
\end{tabular}

${ }^{a}$ Number of internal lesions with bevelling as a proportion of all perforations.

${ }^{b}$ Number of bevelled defects with bone spalls still attached as a proportion of all bevelled defects. 


\section{Table 10}

Descriptive statistics for the area of the internal lesions and internal to external area ratio for all internally bevelled defects produced by the three arrow types.

\begin{tabular}{llllll}
\hline & & $\begin{array}{l}\text { Broadhead } \\
(n=7)\end{array}$ & $\begin{array}{l}\text { Bodkin } \\
(n=9)\end{array}$ & $\begin{array}{l}\text { Barbed broadhead } \\
(n=3)\end{array}$ & $\begin{array}{l}\text { All } \\
(n=19)\end{array}$ \\
\hline Int. area $\left(\mathrm{mm}^{2}\right)$ & Mean & 143.44 & 187.08 & 275.75 & 185.00 \\
& Median & 120.30 & 168.62 & 268.46 & 133.36 \\
& SD & 117.67 & 176.29 & 147.82 & 151.33 \\
& Min. & 42.66 & 32.54 & 131.70 & 32.54 \\
& Max. & 396.33 & 629.56 & 427.08 & 629.56 \\
Int./ext. ratio & & & & 6.69 \\
& Mean & 3.88 & 5.91 & 15.59 & 4.69 \\
& Median & 3.86 & 6.24 & 5.50 & 7.98 \\
& SD & 1.42 & 2.90 & 19.62 & 2.04 \\
& Min. & 2.04 & 2.11 & 3.08 & 38.20 \\
\hline
\end{tabular}

\section{Table 11}

Summary of main characteristics of puncture lesions produced by broadheads, bodkins, and barbed broadheads .

\begin{tabular}{llll}
\hline & Broadhead & Bodkin & Barbed broadhead \\
\hline Type & Punctures and few fractures & $\begin{array}{l}\text { Punctures and few } \\
\text { fractures }\end{array}$ & $\begin{array}{l}\text { Punctures, few fractures and } \\
\text { few shallow, cut-like marks }\end{array}$ \\
Penetration & $\begin{array}{l}\text { About half of punctures are } \\
\text { perforations with internal } \\
\text { bevelling }\end{array}$ & $\begin{array}{l}\text { Two-thirds are } \\
\text { perforations with internal } \\
\text { bevelling }\end{array}$ & $\begin{array}{l}\text { One-third are perforations with } \\
\text { internal bevelling }\end{array}$ \\
Shape & $\begin{array}{l}\text { Elliptical or rounded, flat } \\
\text { lozenge }\end{array}$ & Square or rhomboid & $\begin{array}{l}\text { Elliptical with narrow, sharply } \\
\text { pointed extremities }\end{array}$ \\
$\begin{array}{l}\text { Margin } \\
\text { damage }\end{array}$ & $\begin{array}{l}\text { Feathers are wispy, flake-like } \\
\text { or splinter-shaped, mostly } \\
\text { unilateral, flaking rare }\end{array}$ & $\begin{array}{l}\text { Flake-like feathers, mostly } \\
\text { unilateral, flaking rare }\end{array}$ & $\begin{array}{l}\text { Variable, mostly unilateral } \\
\text { damage to margins, some } \\
\text { flaking; uneven, ragged margins }\end{array}$ \\
\hline
\end{tabular}

